\title{
Membrane and Adsorption Processes for Removing of Organics and Inorganics from Urban Wastewaters
}

\author{
MAJLINDA DACI-AJVAZI ${ }^{1}$, BASHKIM THAÇI ${ }^{1 *}$, NEXHAT DACI ${ }^{2}$ and SALIH GASHI ${ }^{2}$ \\ ${ }^{1}$ Chemistry Department, University of Prishtina, Republic of Kosovo. \\ ${ }^{2}$ Academy of Sciences and Arts of Kosovo, Republic of Kosovo. \\ ${ }^{*}$ Corresponding author E-mail: bthaqi75@gmail.com \\ http://dx.doi.org/10.13005/ojc/320510
}

(Received: August 22, 2016; Accepted: October 13, 2016)

\begin{abstract}
Since in Kosovo there are still no water purification plants and untreated wastewaters are discharged in environment, in this paper we've studied methods for removing of different organic and inorganic pollutants from Kosovo urban wastewaters. For best results we've used two methods, reverse osmosis and adsorption. For reverse osmosis, all samples were pretreated with coagulant $\left(\mathrm{FeSO}_{4}\right)$ and flocculant $(\mathrm{CaO})$ and then treated with reverse osmosis membranes. For adsorption, we used Kosovo coal ash and bentonite, both natural and low cost adsorbents. The analysis of experimental results shows that removing of organic and inorganic pollutants by reverse osmosis was very effective and removed from $93-98 \%$ of organics and almost $100 \%$ of heavy metal ions. Efficiency of coal ash in removing organics from natural waters was from $88-95 \%$, while the efficiency of bentonite was $77-88 \%$, while removing of heavy metal ions by coal ash was from $79-100 \%$ and by bentonite was from $50-92 \%$ respectively.
\end{abstract}

Keywords: coal ash, reverse osmosis, membranes, bentonite, adsorbtion.

\section{INTRODUCTION}

Coal as fossil fuel is the most abundant fossil fuel resource in most countries including Kosovo, and many studies described it as the bridge to future energy systems, while stressing world coal prospects, environmental problems, resources and energy projections ${ }^{1-3}$. Many studies are also oriented on finding ways for improving the adsorption properties of coal through different modification ${ }^{4,5}$.
Kosovo, although small in area $\left(10,908 \mathrm{~km}^{2}\right)$, it is rich in energy resources and lignite type coal is the main national natural resource. Coal, as a lignite type, was and still is a very important natural resource that was extensively used as main energy resource for a half century. In this process, the existing thermal power plans discharge extremely large ash amounts, deposited in landfills which in turn largely pollute surface and underground waters and environment ${ }^{6,7}$. 
Lignite type coal in Kosovo was extensively used in electricity power plants. Unfortunately the exploitation of lignite was done without respect to environmental capacity of the country and almost has created an environmental bomb for population. Uncontrolled burning of lignite in power plants each year left in Kosovo environment about 2 million tons of fly and bottom ashes, more than 100 thousand $t$ of sulphur, of which more than $50 \%$ organic, over 11 t of arsenic, more than 2 t of beryllium, 1 t of cadmium, $351 \mathrm{t}$ of nickel, $492 \mathrm{t}$ of titanium, $191 \mathrm{t}$ of manganese, $0.48 \mathrm{t}$ vanadium, etc. This uncontrolled burning of lignite in Kosovo power plants, jeopardize both our public health and our environment ${ }^{8,9}$.

Since coal is main natural resource of Kosovo, we've used it in reverse osmosis for modification of membranes and in adsorption for removing of different pollutants from natural and wastewaters. Since Kunst and Sourirajan ${ }^{10}$ produced productive asymmetric cellulose acetate membranes for a low pressure reverse osmosis application many investigations have been initiated for further development of these membranes. Exploitation of new membrane materials, modification of existing membrane materials by using chemical or physical methods such as plasma modification radiation induced grafting, surface chemistry reaction, surface coat and blend method have been frequently used. Especially, the blend method has become widespread and efficient to prepare a good membrane ${ }^{11}$. In order to obtain membranes with specific properties, additional additives can be added to the casting solution. Coal was used as new material to prepare heterogeneous reverse osmosis membranes ${ }^{12}$. It was found that aryldiazonium salts at low concentration in their organic or aqueous solution are materials able to be electrochemically reduced on carbon semiconductors ${ }^{13-15}$ or conductors ${ }^{16}$. Therefore, this coal was modified with 4- nitrobenzene diazonium salt in acetonitrile or hydrochloric acid. The membranes from cellulose acetate and coal modification show more productivity in comparison than that non modified coal ${ }^{17}$. The modified coal with 4- nitrobenzene diazonium salt shows encouraging results for preparation of heterogeneous reverse osmosis membranes.

Reverse osmosis membrane can be well protected by pretreatment, as it is a significant determinant for employing water reuse plants in remote areas ${ }^{18}$. Currently, reverse osmosis feed pretreatment is mainly used to reduce suspended and colloidal material in the feed water. Conventional pretreatment includes disinfection, flocculation/ coagulation and filtration processes, including microfiltration or ultra filtration ${ }^{19}$. In the last decades, on many occasions, the membrane processes looks more and more promising as separation processes in industry and waste water treatment.

Among various water purification and recycling technologies, adsorption is a fast, inexpensive and universal method. Activated carbon is considered as universal adsorbent for the removal of diverse types of pollutants from water. The use of various low-cost adsorbents (from organic precursors like fertilizer industry wastes, fly ash, biomass, peat, fruit stones etc. and inorganic precursors including red mud, clays, blast zeolites etc.,) as substitutes for the costly activated carbon, have been extensively studied and have led to the rapid growth of research interests in this field ${ }^{20-22}$. Heavy metals pose a significant threat to environment and public health because of their toxicity, accumulation in the food chain and persistence in nature. Adsorption technology is one of the best water treatment technologies and has been used extensively for the uptake of toxic metal ions from ground, surface and wastewater.

Continuously increasing demand for raw materials and the limited availability of natural resources, as well as extensively used lignite type coal for producing energy gave rise to the investigation of possible reuse of fly ash and bentonite for extracting valuable trace elements or as adsorption material for heavy metals as pollutant in water streams ${ }^{23-26}$. Bentonite, another natural occurring material shows a wide range of industrial applications. It's abundance in most countries and its low cost makes it a suitable adsorbent for the removal of many pollutants ${ }^{27}$. For removal of organics and inorganics from water samples we've used coal ash as adsorbent, which meet dual goals of disposal and treatment, and as comparison we've used bentonite. Although both used adsorbents are alum silicates, they differ in their composition. There is predominance of alkaline components $(\mathrm{CaO}$ and 
$\mathrm{MgO}$ ) in Kosovo coal ash and in bentonite there is predominance of acid components $\left(\mathrm{SiO}_{2}, \mathrm{Al}_{2} \mathrm{O}_{3}\right)$.

\section{MATERIALS AND METHODS}

\section{Coal modification}

The coal specimens were treated with boiling water (353K) under stirring conditions. The residual coal after filtering was dried at 378 $\mathrm{K}$ to constant weight. Typically $8 \mathrm{~g}$ of this coal was dispersed in $100 \mathrm{~cm}^{3}$ phosphoric acid containing 15 $\mathrm{mM}$ of $\mathrm{N}_{2} \mathrm{C}_{6} \mathrm{H}_{4} \mathrm{BF}_{4}$. The solution was stirred at $278 \mathrm{~K}$ in controlled water bath for $5 \mathrm{~h}$. The reaction mixture was filtered with a 589 Blue ribbon and then the modified coal was washed by successive aliquots of water. Finally the modified coal was dried at $378 \mathrm{~K}$ to the constant weight, ground and sieved. The coal fractions of sieve size of $\sim 170$ mesh were used in this study.

\section{Film casting details}

The film casting details for the investigated membranes are casting solution composition cellulose acetate (E 398-3) 10 wt\%, modified coal with aryldiazonium salt 15 wt $\%$, with corresponding amounts of acetone $61.3 \mathrm{wt} \%$, water $12.25 \mathrm{wt} \%$, and magnesium perchlorate $1.45 \mathrm{wt} \%$ at temperature of casting solution and casting atmosphere $297 \mathrm{~K}$ and ambient air (relative humidity 60\%). The films were cast on a clean glass plate $(22 \times 38 \mathrm{~cm})$ with the use of a metal cylinder with uplifted edges to obtain the required film thickness $(0.12 \mathrm{~mm})$. The glass plate was kept at the same temperature as the casting solution. The casting solution temperature and the external conditions of solvent evaporation time (0s) during film casting were the same for all series of films studied. The cast solution was immediately dipped into a gelatin bath consisting ice cold water (273K). The duration of the film setting in ice cold water was $1 \mathrm{~h}$. Before the reverse osmosis experiment, the membranes were preshrunk under water at different temperatures (the temperature of water bath was controlled to within $\pm 0.5 \mathrm{~K}$ ) and initially each film was subjected to pure water pressure treatment for $1 \mathrm{~h}$ at $20 \%$ higher pressure than that to be used in reverse osmosis run. The surface area of the membranes investigated was $11.92 \mathrm{~cm}^{2}$.

Permeate flow rate, referring to the membrane-permeated solution corrected to $298 \mathrm{~K}$, and the rejection factor $\mathrm{R}$, defined as:

$$
R=1-\frac{C_{p}}{C_{f}}
$$

$\mathrm{Cp}$ and Cf - permeate and feed concentrations (g/ $\left.\mathrm{dm}^{3}\right)$.

\section{Pretreatment step}

First the urban waste waters were treated by $\mathrm{FeSO}_{4}$ and $\mathrm{CaO}$ in proportion 0.05:0.125 g/ $\mathrm{dm}^{3}$. This step was used as pretreatment method. After that these waste waters are treated with reverse osmosis membranes. After pretreatment the $\mathrm{pH}$ was increase till 10.7, so we used some drops $\mathrm{H}_{2} \mathrm{SO}_{4}$ to decrease $\mathrm{pH}$ to 7 , because the membranes degrade in this $\mathrm{pH}$.

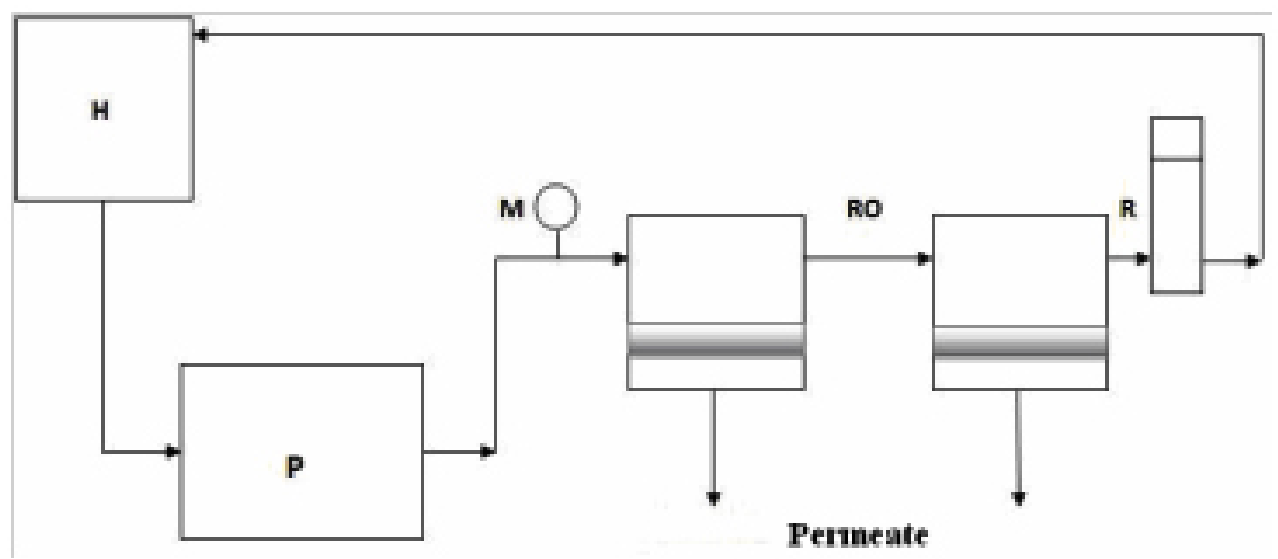

Fig. 1: Schematic representation of reverse osmosis set-up. $\mathrm{H}$-hold tank, P-high pressure pump, M-manometer, RO-reverse cells, R-back pressure regulator 


\section{Reverse osmosis apparatus}

The membranes, five samples of each type, were tested in a laboratory reverse osmosis apparatus illustrated schematically in Fig. 1

\section{Adsorption}

As adsorbents we used coal ash from Kosovo thermo power plants (Kosova $A$ and Kosova B) and bentonite. They were dried at $105^{\circ} \mathrm{C}$ and calcinated at $800^{\circ} \mathrm{C}$. Physical-chemical characteristics of adsorbents were determined with standard analytical methods (Table 3).

$1 \mathrm{~g}$ of coal ash/bentonite was added to a certain volume of water sample $\left(100 \mathrm{~cm}^{3}\right)$. Solution was continuously mixed with magnetic stirrer for 30 minutes. After completion of the reaction time, the mixture was filtered and analyzed.

Physical-chemical analysis of the water samples: turbidity (TUR), conductivity (EC), $\mathrm{pH}$, temperature, dissolved oxygen (DO), chemical oxygen demand (COD), biological oxygen demand (BOD), total organic carbon (TOC), total suspended solids (TSS), total dissolved solids (TDS), surfactants (SUR), nitrate ions $\left(\mathrm{NO}_{3}{ }^{-}\right)$, phosphate ions $\left(\mathrm{PO}_{4}{ }^{3-}\right)$, total phosphorus $\left(\mathrm{P}_{\text {tot }}\right)$, ammonium ions $\left(\mathrm{NH}_{4}^{+}\right)$, sulphate ions $\left(\mathrm{SO}_{4}{ }^{2-}\right)$ and analysis of heavy metal ions: $\mathrm{Pb}^{2+}, \mathrm{Cd}^{2+}, \mathrm{Fe}^{2+}, \mathrm{Ni}^{2+}, \mathrm{Cr}^{3+}, \mathrm{Zn}^{2+}, \mathrm{Mn}^{2+}$ and $\mathrm{Cu}^{2+}$ were done before and after treatment with $\mathrm{FeSO}_{4} /$ $\mathrm{CaO}$, reverse osmosis, coal ash and bentonite. Temperature, $\mathrm{pH}$, EC and TDS were measured directly with HI98130 instrument. COD, BOD, TOC, SUR, $\mathrm{NO}_{3}^{-}$were measured directly with Pastel UVSecoman instrument. DO was measured directly with instrument $\mathrm{HI} 9146$. For $\mathrm{PO}_{4}{ }^{3-}$, (ammonium molibdate method), total phosphorous $\mathrm{P}_{\text {tot }}$ (ammonium persulfate method) and for $\mathrm{NH}_{4}^{+}$Visible Light premiums Secoman spectrophotometer was used. For $\mathrm{SO}_{4}{ }^{2-}$ standard sodium thiosulfate titration method was used. Heavy metal ions were analyzed with atomic absorber 400 Perkin Elmer.
Samples: S1 - urban waste waters of capital city of Kosovo, Pristina, S2 - urban waste waters of Prizren city, S3 - urban waste waters of Mitrovica city and S4 - urban waste waters of Ferizaj city.

\section{RESULTS AND DISCUSSION}

Extensively used lignite type coal for producing energy, abundance of bentonite in nature and also their low cost makes them suitable adsorbents for the removal of many pollutants. In terms of physical-chemical properties, chemical composition of ash varies greatly, depending on the type of coal and its origin. Coal ash from our lignite type coal has specific inorganic composition. The results that were achieved in determining chemical composition of Kosovo coal ash and bentonite are shown in Table 1.

From the features shown in Table 1 , it is expected that metal ions in water samples, will mostly be absorbed by silicon oxides, aluminum oxides or iron oxides, or by influence of combination of these oxides. It is assumed that the predominance of alkaline components ( $\mathrm{CaO}$ and $\mathrm{MgO}$ ) in Kosovo coal ash, will also affect the precipitation of some metal ions.

Comparative analysis of the two materials used as natural adsorbents, show the differences in their composition. Although both used adsorbents are alumosilikates, bentonite differs from the domination of acidic constituents ( $80 \%$ ) to those alkaline (20\%), while in coal ash dominates alkaline constituents (80\%) to those acidic (20\%)

From the features shown in Table 2, we can see that these waters have $\mathrm{pH}$ 7.93-8.94 and high electrical conductivity and TDS. From data for COD, BOD and TOC it can be seen that these waters are polluted.

Table 1: Chemical composition of Kosovo coal ash and bentonite

\begin{tabular}{lccccccccc}
\hline Adsorbents & $\begin{array}{c}\text { Loss } \\
\text { on ignition }\end{array}$ & $\mathrm{SiO}_{2}$ & $\mathrm{Al}_{2} \mathrm{O}_{3}$ & $\mathrm{Fe}_{2} \mathrm{O}_{3}$ & $\mathrm{CaO}$ & $\mathrm{MgO}$ & $\mathrm{Na}_{2} \mathrm{O}$ & $\mathrm{K}_{2} \mathrm{O}$ & $\mathrm{TiO}_{2}$ \\
\hline Coal ash \% & 2.20 & 26.75 & 4.00 & 10.77 & 41.48 & 4.36 & 1.42 & 0.16 & 0.50 \\
Bentonite \% & 6.091 & 65.11 & 9.07 & 3.69 & 0.68 & 1.27 & - & - & - \\
\hline
\end{tabular}


Experience from membrane waste water treatment has demonstrated that key design parameters must be followed to prevent rapid membrane fouling, and thus reduce height system maintenance costs and significant downtime. Chemical pretreatment process is one of the most popular methods for waste water pretreatment due to its low cost and simplicity. Pretreatment objectives, is to make the waste water to the reverse osmosis compatible with the membrane. Pretreatment is required to increase the efficiency and life expectancy of the membrane elements by minimizing fouling, scaling and degradation of the membrane. Inadequate pretreatment often necessitates frequent cleaning to restore product flux and rejection. This will result in excessive chemical cleaning costs, and in severe cases will result in permanent loss of performance, membrane degradation and therefore shorter membrane life. So, we used coagulant $\left(\mathrm{FeSO}_{4}\right)$ and flocculant $(\mathrm{CaO})$ to pretreate water samples $\left(\mathrm{S}_{1}, \mathrm{~S}_{2}, \mathrm{~S}_{3}\right.$, and $\left.\mathrm{S}_{4}\right)$, see Table 2, 3 and Figure 1, 2.

From Table 2 and Figure 2 it can be seen the effect of chemical pretreatment with $\mathrm{FeSO}_{4} / \mathrm{CaO}$ in reduction of $\mathrm{COD}, \mathrm{Pt}, \mathrm{NO}_{3}^{-}$by $53.4 \%, 58.9 \%$, $60.1 \%$, As we see from the data this step is very important. After the pretreatment samples were treated with reverse osmosis (RO) membranes. RO membranes can remove dissolved solids which can't be removed by chemical and biological or other conventional municipal treatment process. Same tables and figures show the results of $\mathrm{RO}$ membranes. From these data we can see that RO

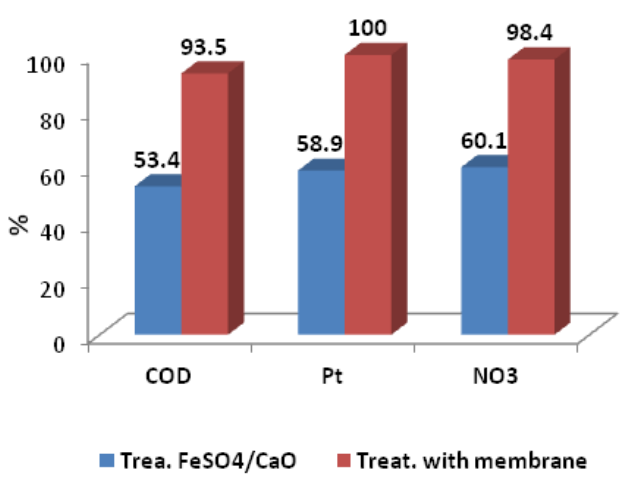

Fig. 2: Percentage of removal of COD, Ptot and $\mathrm{NO}_{3}^{-}$after pretratment with $\mathrm{FeSO}_{4} / \mathrm{CaO}$ and after treatment with RO membrane membranes have shown significant reduction of: TDS (95-97\%), COD (93-98\%), BOD (96-97\%), TOC $(97 \%)$, EC (95-97\%). The flux of these membranes was $4.9 \times 10^{-2} \mathrm{~m}^{3} / \mathrm{h} / \mathrm{m}^{2}$.

From Table 2 and Figure 3 data results for DO 5.5-6.8 mg/dm ${ }^{3}$, COD 71.4-133 mg/dm ${ }^{3}$, BOD 27-63 mg/dm ${ }^{3}$, and TOC $20-43.6 \mathrm{mg} / \mathrm{dm}^{3}$ show that we are dealing with polluted areas which correlate with TDS $289-438 \mathrm{mg} / \mathrm{dm}^{3}$ and TSS $65-238 \mathrm{mg} / \mathrm{dm}^{3}$ results.

Reduction of TSS plays a significant role in modern wastewater treatment, since the SS serves as an adsorbent for heavy metals and polychlorinated biphenyls (PCBs). Results from Table 2 show that removal of TSS by coal ash was very effective from $73-100 \%$ and by bentonite from $61-80 \%$. The presence of excess nitrogen and its compounds has a negative impact on the environment. Nitrogenous compounds play an important role in water pollution, therefore, the control of them in water has vital importance. Efficiency of removal of nitrate ion and ammonium ion from the treated water samples was high. Removal of nitrate ion by coal ash was $100 \%$, with bentonite $95-100 \%$, while removal of ammonium ion by coal ash was $87-95 \%$ and by bentonite $71-93 \%$ respectively. High levels of organic pollutants into river water affect the suitability of river water for human use and it stimulates the growth of algae and aquatic plants. Various treatment methodologies have been used for the removal of organic pollutants but most of them are complicated and time-consuming, except for adsorption methods,

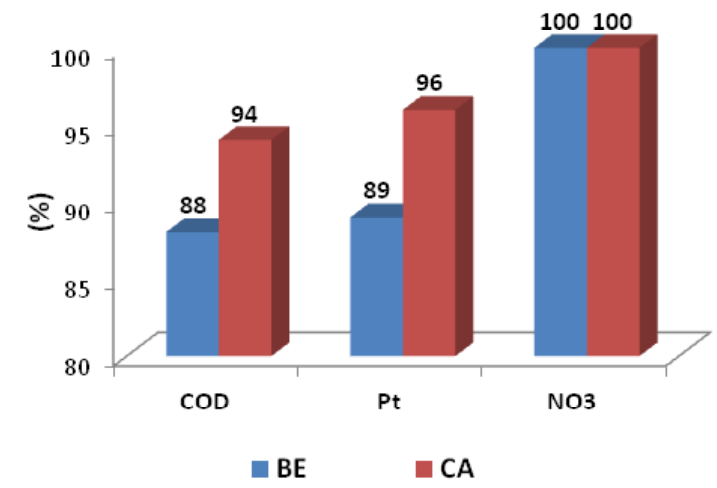

Fig. 3: Percentage of removal of COD, $\mathrm{P}_{\text {tot }}$ and $\mathrm{NO}_{3}^{-}$by coal ash and bentonite 


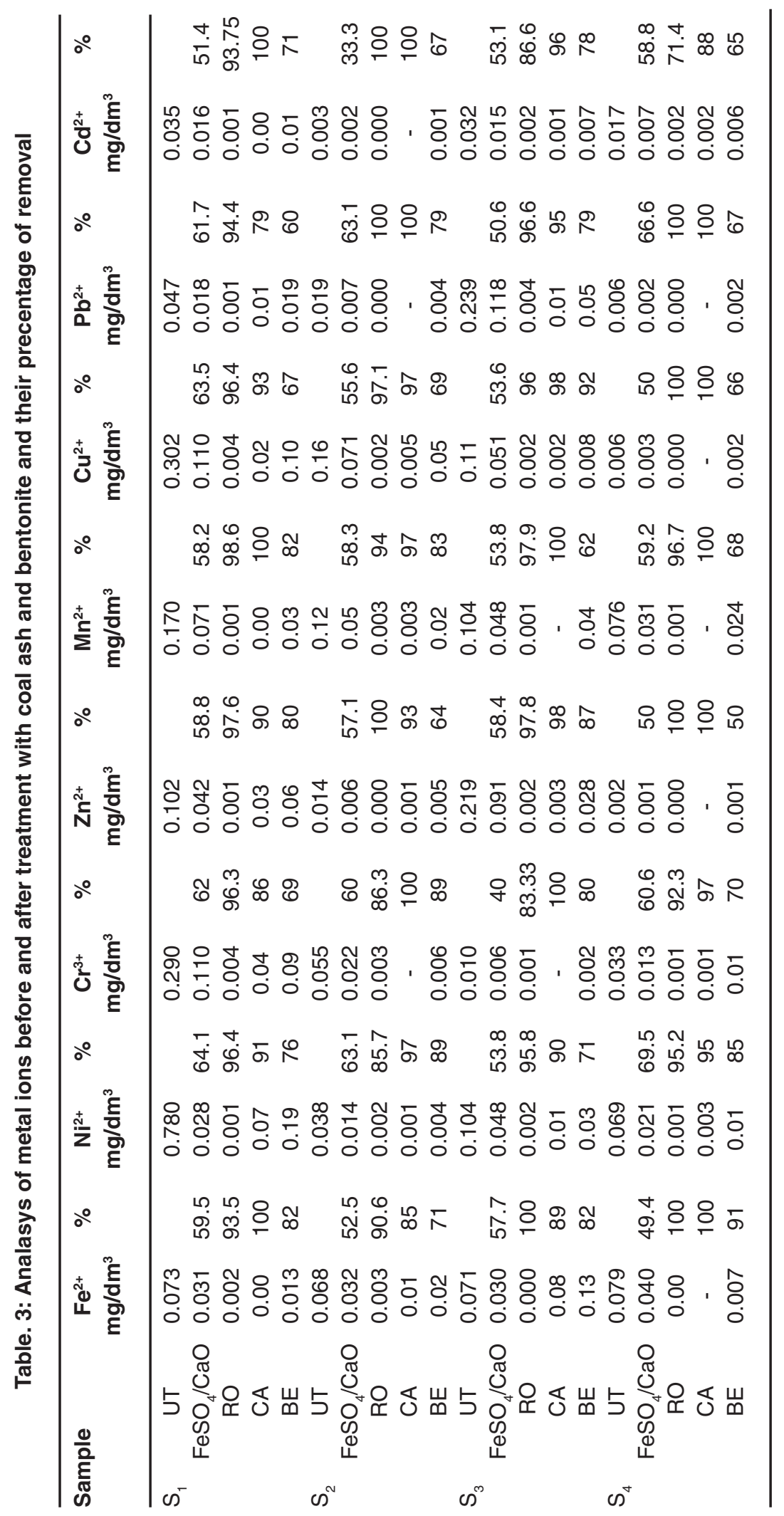




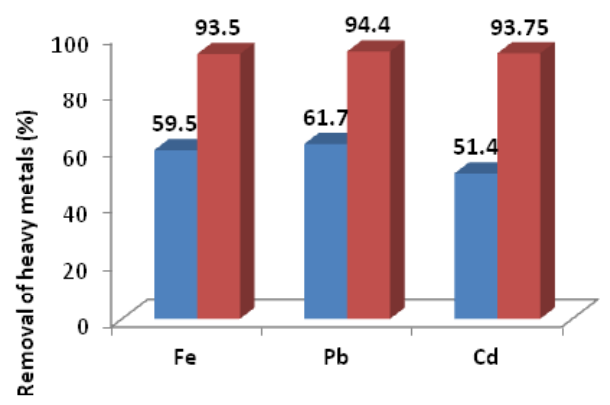

Trea. $\mathrm{FeSO} 4 \mathrm{CaO} \quad$ Treat. with membrane

Fig. 4: Percentage of removal of heavy metal ions after pretratment with $\mathrm{FeSO}_{4} / \mathrm{CaO}$ and after treatment with RO membrane

which are low cost and easy to use. Coal ash and bentonite were very effective adsorbents for removal of organics. Removal of COD by coal ash was from $83-94 \%$ while with bentonite was $73-88 \%$. The removal of total phosphorus by adsorption is simple and convenient. Results from Figure 2 show the removal of total phosphorus by coal ash was from $87-96 \%$ while with bentonite was $76-89 \%$.

Table 2 shows that $\mathrm{pH}$ before and after treatment with coal ash are very different. $\mathrm{pH}$ values revolve primarily in line with the guiding values for waters discharged into natural ecosystems, before treatment they range from 7.93-8.94, after treatment with coal ash the $\mathrm{pH}$ values were increased up to 14 , which is expected due to the composition of the ash, and after treatment with bentonite the $\mathrm{pH}$ values were increased from $9.44-10.8$ respectively. As for conductivity values before treatment they vary from $568-798 \mu \mathrm{S} / \mathrm{cm}$ and after treatment with coal ash the EC values were increased from 1175$2030 \mu \mathrm{S} / \mathrm{cm}$, while after treatment with bentonite EC values were $623-840 \mu \mathrm{S} / \mathrm{cm}$.

From the features shown in Table 3 and Figure 4 it can be seen the effect of chemical pretreatment with $\mathrm{FeSO}_{4} / \mathrm{CaO}$ in removal of heavy metal ions $\mathrm{Fe}^{2+} \mathrm{Pb}^{2+}$ and $\mathrm{Cd}^{2+}$ by $57.5 \%, 61.7 \%$, $71.4 \%$. Same tables and figures show the results of RO membranes. From these data we can see that RO membranes have shown almost complete removal of heavy metals: $\mathrm{Fe}^{2+}(90-100 \%), \mathrm{Ni}^{2+}(85-$ $96 \%), \mathrm{Cr}^{3+}(83-96 \%), \mathrm{Zn}^{2+}(97-100 \%), \mathrm{Mn}^{2+}(94-$

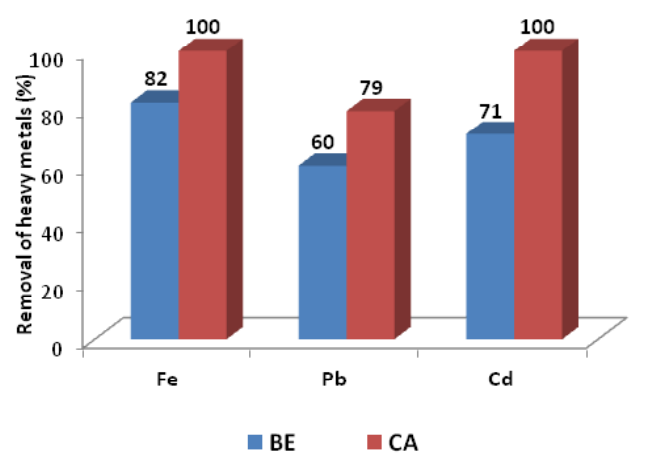

Fig. 5: Percentage of removal of heavy metal ions by coal ash and bentonite

98\%), $\mathrm{Cu}^{2+}(96-100 \%), \mathrm{Pb}^{2+}(94-100 \%)$ and $\mathrm{Cd}^{2+}(71-100 \%)$. These data indicates that resulting membranes are readily available and effective for treatment of municipal waste waters. The development of these membranes is of great interest for wide variety of low pressure reverse osmosis membranes especially for waste water treatment.

From Table 3 and Figure 5 it can be seen that both used absorbent showed very good sorption properties. Percentage of removal of heavy metal ions with coal ash was from $85-100 \%$ while with bentonite was from $50-92 \%$. Increasing $\mathrm{pH}$ during adsorption indicates that the high efficiency of Kosovo coal ash in removing of metal ions can be attributed to two processes, the adsorption and precipitation process as a result of hydrolysis of the alkaline oxides in sodium and magnesium hydroxides which help precipitation of certain metal ions. The adsorption process is a result of characteristic structure of our coal, its high porosity and large surface area.

\section{CONCLUSION}

Based on the results that were achieved we can conclude that success of membrane processes depends on proper pretreatment, chemical control and $\mathrm{RO}$ membranes that are resistant to fouling. Data from this paper shows that these membranes are readily available and effective for treatment of municipal waste waters. The development of these membranes is of great interest for wide variety of low pressure reverse osmosis membranes especially 
for waste water treatment. Kosovo coal ash and bentonite show good sorption capacity toward heavy metal ions and other pollutants with high sorption rates of over $90 \%$ of the total adsorption which can be obtained in thirty minutes of contact time.

\section{REFERENCES}

1. Ishaq, M., Saeed, K. Ahmad, I. Sultan, S., Coal Ash as a Low Cost Adsorbent for the Removal of Xylenol Orange from Aqueous Solution, Iranian Journal of Chemistry and Chemical Engineering, 2014,. 33, 1.

2. Geetha V. Ram, Vaishali, S. A comparative study on the removal of heavy metals by adsorption using fly ash and sludge: A review, International Journal of Application or Innovation in Engineering \& Management, 2013,. 2(7), 2319 - 4847.

3. WorldEnergy: Looking ahead to 2020; Published for the World Energy Conference by IPC Science and Technology Press, London.

4. Samson, B. Sanja, V., Evaluation and Treatment of Coal Fly Ash for Adsorption Application, Leonardo Electronic Journal of Practices and Technologies, ., 2008, 12., 3748, , ISSN 1583-1078.

5. Wang, S. Soudi, M. Li, L. Zhu, ZH., Coal ash conversion into effective adsorbents for removal of heavy metals and dyes from wastewater, Journal of Hazard Materials, 2006, 243-51

6. Daci, N.M., , Environmental Protection Engineering,1989, 4, 3-4.

7. Daci, N.M., Inovation, Industried Progress and Environment, 1991, 1-9, Strasburgh.

8. Zeneli, L., Daci, N., Daci-Ajvazi, M., Paçarizi, H., Effects of pollution on lead and cadmium concentration and correlation with biochemical parameters in blood of human populationnearby Kosovo thermo power plants, American Journal of Biochemistry and Biotechnology,2008, 4 (3): 273-276

9. Zeneli, L., Daci, N., Paçarizi, H., DaciAjvazi, M., Interaction between cadmium and calcium in human blood at smokers, American Journal of Pharmacology and Toxicology, 2010, 5(1): 48-51

10. Kunst, B., Sourirajan, S., Development and performance of some porous cellulose acetate membranes for reverse osmosis desalination, J. Appl. Polym. Sci., 1970, 14, 2559.

11. Zhou, Ch., Wang, Zh., Liang, Y., Yao, J., Study on the control of pore sizes of membranes using chemical methods Part II. Optimization factors for preparation of membranes, Desalination, 2008, 225, 123138

12. Gashi, S.T., Daci, N.M, Selimi, T., Reverse Osmosis Properties of Cellulose AcetateCoal membranes. Environmental. Menagment for Developing Countries, 1984, 405, 1-9.

13. Allongue P., Delamar M., Desbat B., Fagebaume O., Hitmi R., Pinson J. and Saveant J.M.), Covalent modification of carbon surfaces by aryl radicals generated from the electrochemical reduction of diazonium salts, Journal of American Chemical Society., 1996, 119, 201-207

14. Belmont J.A., Amici R.M., Galloway C.P., (Cabot Corp.) PCT WO 18688, Chemical Abstract, 1996, 125, 144-212.

15. Toupin $\mathrm{M}$, and Belanger $\mathrm{D}$, Thermal stability study of aryl modified carbon black by in situ g enerated diazonium salt, Journal of Physical Chemistry, 2007, 14, 5394-5401,

16. Pinson $\mathrm{J}$ and Podvorica F., Attachment of organic layer to conductive or semiconductive surfaces by reduction of diazonium salts, Chemical Society Reviews. 2005, 34, 5, 429-439

17. Gashi S.T., DaciN.M., Podvorica F., Selim. T., Thaçi B., Effect of the modification time of coal with aryldiazonium salts on performance of cellulose acetate- coal heterogeneous reverse osmosis membranes, Desalination, 2009 240, 1-8

18. Zhang J, Northcott, K, Duke, M, Scales, P., Stephen, R.G., Influence of pretreatment combinations on RO membrane fouling, Desalination,2016., 393, 120-126,

19. Ebrahim S., Abdel-Jawad M., Bou-Hamad S., Safar M. Fifteen years of R \& amp; D program in seawater desalination at KISR 
part I. pretreatment technologies for ROsystems, Desalination, 2001, 135, 141153

20. Alinnor, I .J., Adsorption of heavy metal ions from aqueous solution by fly ash, Fuel, 2007, 86,. 853-857,

21. Gupta, V.K., Ali, I., Water Treatment for Inorganic Pollutants by Adsorption Technology, Environmental Water, 2013, 2991,

22. Jiuhui, Q.U., Research progress of novel adsorption processes in water purification: a review, Journal of environmental sciences, 2008, . 20, 1-13,

23. Ahsan, S., Kaneco, S., Ohta, K., Mizono, T., Kani, K., , Use of some natural and waste materials for waste water treatment. Water Resorces. 2001.,35, 3738-3742,

24. Gupta, V.K., Ali, I., Advances in water treatment by adsorption technology, Nature protocols, 2006, 1, 2661-2667

25. Amit, B., Minocha, A.K.,, Conventional and nonconventional adsorbents for removal of pollutants. Indian Journal of Chemical Technology,2006., 13, 203-217,VAN 14.139.47.15.

26. Kirk, D.W., Charles, Q., Jia, J.Y., Alan, L.T., Wastewater remediation using coal ash, Journal of Mateial Cycles and Waste Managment, 2003, 5, 5-8.

27. Vega, J.L., (2005), Bentonite as adsorbent of heavy metal ions from mine waste leachates, 9th International Mine waste Congress. 